\title{
THE CONSTITUTIONAL AND LEGAL ENSHRINEMENT OF THE RIGHT TO INFORMATION. THE IMPACT OF STATES OF EMERGENCY UPON THE RIGHT TO INFORMATION
}

DOI: $10.47743 /$ rdc-2019-2-0002

\author{
Anca-Jeanina NIŢ̌, PhD \\ Lecturer, Faculty of Law and Administrative Sciences, \\ Ovidius University of Constanta
}

\section{Abstract}

Starting from the premise that information is the raw material of a democratic society, the present article aims to showcase the importance of the constitutional regulation of the right to information.

Observing Article 31 of the Romanian Constitution and the infraconstitutional norms in the field of free access to information of public interest, which further develop the constitutional norm, this paper presents the content of the right to information and its limits.

Moreover, some legal literature currents and the case law of the Constitutional Court of Romania are emphasized with regard to the restriction in the exercise of this right, under the conditions of Article 53 of the Constitution.

Without detailing the complexity of the legal consequences that derive from declaring a state of emergency, there are identified the limits under which, in such cases, the restriction of some fundamental rights and liberties that can occur.

In the current normative context, while insisting that exceptional measures must not find themselves outside the existing constitutional order, the present paper analyses the impact of Decree no. 195/2020 for declaring a state of emergency on the territory of Romania upon the right to information.

The article emphasizes that the multiple social, economic and political consequences of such a crisis cannot be dissociated from their legal dimension, that the constitutional rigor of a correct information to the general public through media, both public and private, necessary irrespective of a state of emergency, is needed even more so under exceptional circumstances, where the fight against disinformation is by all accounts legitimate and required.

At the same time, it is emphasized the requirement that a state of emergency isn't used as a pretext for tighter governmental control over information release, for the amputation of the mechanism introduced by Law no. 544/2001 on the free access to information of public interest.

Keywords: right to information; public interest; state of emergency; restricting the exercise of fundamental rights or freedoms; constitutional order 


\section{Introductory remarks}

Citizens' participation in public life without access to information is hard to conceive. To paraphrase Marx, "information is the most valuable capital". Access to information enables the citizen to develop an opinion in relation to the society in which he or she lives and the ways in which the authorities which govern it act.

Also known as the "oxygen of democracy", information is the essence of social progress and the sending and receiving of it constitutes, without any doubt, the "raw material" of a democratic society.

Critically linked to freedom of expression, the right to information is capitalized by each person in order to understand surrounding phenomena and to take part in full comprehension to economic, social and political life.

A century of information and information technology is unconceivable in the absence of a legal consecration of the right to information, of the acknowledgement and enforcement of access to information.

Human rights are established worldwide or at regional level through international treaties and at national level through constitutions and laws - at the center of the preoccupations of any organism that recognizes such rights are those rights which safeguard the equality of all people, their possibility of unrestrained manifestation, in virtue of dignity and liberty, for the man, by his very nature, is a worthy and free being ${ }^{1}$.

Fundamental rights - the legal foundation of the ensemble of citizens' rights - are subjective rights, enshrined in the text of the Constitution, which invests them with special legal safeguards.

In Europe, from the viewpoint of the tradition of regulating the right to access public information, Sweden is one of the first states that established such rules at constitutional level, since 1766.

The access to information of public interest has become, in recent years, one of the most important criteria of classifying a country as democratic or not. Regardless of terminological variations ("freedom of information", "administrative transparency", "open government"), the access to information of public interest currently forms part of a democratic acquis applied to a higher degree by any country which pretends to have a responsible government ${ }^{2}$.

\footnotetext{
${ }^{1}$ N. Popa, The general theory of law, C.H. Beck Publishing House, Bucharest, 2012, p. 44.

2 Report on free access to information of public interest in Romania - comparative analysis 2003-2007, https://www.transparency.org.ro/servicii/ghidurile_cetateanului/index.html.
} 


\section{Constitutional and legal enshrinement of the right to information}

From the viewpoint of doctrinal classifications, the right to information is included, amongst other rights and liberties ${ }^{3}$, within the category of social and political rights and liberties identified as "rights and liberties which through their content, may be exercised by citizens at choice either to solve social and spiritual issues, or to take part in government"4.

A journey through the constitutional history of Romania shows that until its enshrinement in the 1991 Constitution, the right to information never had explicit regulation in any previous constitution.

The right to information is a fundamental right received by the 1991 Constitution of Romania from the international legal instruments ${ }^{5}$.

The enshrinement of the right to information in Article 31 in the 1991 Constitution $^{6}$ was followed by the passing of special legislation on this matter: Law no. 544/2001 on the free access to information of public interest ${ }^{7}$, Law no. 182/2002 on the protection of classified information ${ }^{8}$, Law no. 504/2002 of the audiovisual ${ }^{9}$.

\footnotetext{
${ }^{3}$ Social and political rights and liberties: freedom of thought, freedom of expression, right to information, freedom of assembly, secrecy of correspondence.

${ }^{4}$ M. Safta, Constitutional law and public institutions. Vol. I. The general theory of constitutional law. Rights and freedoms, $5^{\text {th }}$ ed., Hamangiu Publishing House, Bucharest, 2019, p. 218.

${ }^{5}$ The resolution adopted by the UN General Assembly in its first session of 1946 provided that "the freedom of information is a fundamental right of man and the founding pillar of all liberties of which protection the United Nations engages to guarantee".

Article 19 para. 2 of the International Covenant on Civil and Political Rights provides that "every person has the freedom to seek, receive and impart information and ideas of all kinds, regardless of frontiers, either orally, in writing or in print, in the form of art, or through any other media of his choice".

Article 19 of the Universal Declaration of Human Rights provides that "every man has the right to receive, seek and spread information and ideas of any kind, regardless of state boundaries".

Article 10 of the ECHR: "the freedom (...) to receive or impart information or ideas without interference by public authorities and regardless of frontiers (...)".

Article 11 of the Charter of Fundamental Rights of the European Union: “(...) the freedom (...) to receive and impart information and ideas without interference by public authorities and regardless of frontiers. The freedom and pluralism of the media shall be respected".

${ }^{6}$ Article 31 of the 1991 Romanian Constitution provides that: "(1) A person's right of access to any information of public interest shall not be restricted.

(2) The public authorities, according to their competence, shall be bound to provide correct information to the citizens in public affairs and matters of personal interest.

(3) The right to information shall not be prejudicial to the measures of protection of young people or national security.

(4) Public and private media shall be bound to provide correct information to the public opinion.

(5) Public radio and television services shall be autonomous. They must guarantee any important social and political group the exercise of the right to broadcasting time. The organization of these services and the parliamentary control over their activity shall be regulated by an organic law".

${ }^{7}$ Published in the Official Gazette of Romania no. 663 of October 23rd, 2001.

${ }^{8}$ Published in the Official Gazette of Romania no. 248 of April 12 $12^{\text {th }}, 2002$.

${ }^{9}$ Published in the Official Gazette of Romania no. 534 of July 22 ${ }^{\text {nd }}, 2002$.
}

\section{CONSTITUTIONAL LAW REVIEW}


Therefore, the free and unrestrained access to any information of public interest represents a basic principle of the relationship between the people and the public authorities, safeguarded by the Romanian Constitution, international acts ratified by the Romanian Parliament, as well as infraconstitutional legislation.

\section{The content of the right to information and its limits}

\subsection{The content of the right to information as regulated by the constitutional norms and infraconstitutional legislation}

The constitutional enshrinement of the right to information has three coordinates: a) safeguarding the access to any information of public interest; b) the obligation to inform citizens on public affairs and issues of personal interest, pertaining to public authorities; c) the media's obligation to correctly inform public opinion.

The constitutional text manages to legally express a complex and dynamic content, safeguarding access to any information of public interest ${ }^{10}$.

Assuring the right to information, the constitutional norm only concerns information of public interest, thus delimiting exactly the dimensions of this right.

Infra-constitutional legislation explicates the sense of the notion of "information of public interest" and enshrines expressions associated to the notion of public interest.

Article 2 para. 1 letter b) of Law no. 544/2001 defines information of public interest as "any information which concerns the activities or results from the activities of a public authority or institution, regardless of its support, form or way in which information is expressed".

In the sense of the law, according to Article 2 para. 1 letter a) of Law no. 544/2001, through public authority or institution one understands "any public authority or institution which uses or administrates public financial resources, any autonomous régie, as well as private society found under the authority of a central or local public authority and which the State or, as the case may be, an administrative-territorial unit is sole or majority shareholder (...)".

Regarding the definition of notions, one must cite prof. Antonie lorgovan, according to whom "any notion assumes the identification of dominant traits of its content, that logically orders them after the rule of genus-differentia, thus delimiting, in the plain of abstract thinking, not only the boundaries of the phenomenon, the process it invokes, but its very essence"11.

We can see that Law no. 544/2001 on the free access to information of public interest does not associate "public interest" with any other condition, it does not refer

\footnotetext{
${ }^{10}$ I. Muraru, E.S. Tănăsescu, Constitutional law and public institutions, $15^{\text {th }}$ ed., vol. I, C.H. Beck Publishing House, Bucharest, 2016, p. 181.

${ }^{11}$ A. Iorgovan, Treaty of administrative law, $3^{\text {rd }}$ ed., ALL Beck Publishing House, 2001, p. 3.
} 
to the legitimate or justified nature of said interest, a manner of action used in other normative acts.

Although it is not contained any explicit provision in it, from the regulation of Law no. 544/2001, one can undoubtedly extract that its provisions are complementary to the provisions of the act that regulates administrative litigation.

Law no. 554/2004 (which abolished Law no. 29/1990), to which Law no. 544/2001 is a special legislation, defines legitimate public interest at Article 2 letter $r$ ) as being "the interest which concerns the legal order and constitutional democracy, the safeguarding of laws, liberties and fundamental duties of citizens, the satisfaction of community needs and public authority competences".

Moreover, Article 31 of the Audiovisual Code ${ }^{12}$ defines the justified public interest, a notion under which one can find "any issue, fact or event which influences society or a community, in particular regarding a) the prevention or demonstration of the committing of a criminal act; b) the protection of public health or safety; c) signaling deceptive affirmations or cases of incompetence which affect the public".

Returning to the constitutional norm, we can observe that by assuring citizens' right to information, the Constitution establishes correlative obligations for public authorities, namely to correctly inform the citizens about public affairs and issues of personal interest, to guarantee the protection of youth and national security.

The main normative consequence of the constitutional text involves the creation of a general positive obligation for the public power to provide and facilitate such guaranteed access for any person to a circumstantiated domain of information of public interest.

In equal measure, from Law no. 544/2011 and the content of the Methodological Norms approved through Government Decision no. $123 / 2002^{13}$ - which develops the principles, procedures and rules for applying the law - it results that free access to information must be seen as a phenomenon which involves, on the one hand, a general obligation of public authorities and institutions, and on the other hand, an individual right of the citizen and media respectively ${ }^{14}$.

Under the provisions of the act regulating free access to information of public interest, the right of any person to information has three dimensions, namely: a) the right to be informed, ex officio, by public institutions or authorities with regard to important aspects concerning their functioning; b) the right to request information; c) the right to be informed by the media with regard to diverse aspects from the public sphere.

\footnotetext{
${ }^{12}$ Decision no. 220/2011 on the Code of regulating audiovisual content, published in the Official Gazette of Romania no. 174 of March $11^{\text {th }}, 2011$.

${ }^{13}$ Published in the Official Gazette of Romania no. 167 of March $8^{\text {th }}, 2002$.

14 The Romanian lawmaker guarantees the free access of media to information of public interest (Article 15 para. 1 of Law no. 544/2001), providing through Article 15 para. 2 of Law no. 544/2001 that "the seeking and spreading of said information by media represents a concretization of the citizens' right to have access to any information of public interest".
} 


\section{The constitutional and legal enshrinement of the right to information}

There are situations in which information is of public interest, but not destined for public knowledge, because this would not satisfy public interest, but would rather harm it.

In full agreement with the constitutional norm - which expressly provides that the right to information must not damage the measures to protect youth or national security, through Article 12 para. 1 of Law no. 544/2001, the lawmaker enumerates the information excepted from the free access of citizens ${ }^{15}$.

With reference to the exception from free access of citizens to information in the field of national defense, security and public order, if they form part of the classified information - Article 12 para. 1 letter a), we can say without fear of mistake that Law no. $182 / 2002$ concerning the protection of classified information is complementary to Law no. 544/2001, detailing the field of classified information and the applicable legal regime.

Certainly, the scope and finality of Law no. 182/2002 is not to limit access to information of public interest, but to regulate measures meant to protect the damaging of general interests of state's safety and security. This results from the clear redaction of Article 24 para. 5 of the Law no. 182/2002 ${ }^{16}$.

At the same time, the mentioned legal provision is in full agreement with Article 13 of the law which regulates access to information of public interest, which mentions without any doubt that one may not classify information which favors or conceals violation of law by public authorities or institutions.

Due to the meaningfulness of enforcing the media's right to information, the Constitution enshrines, in Article 31 para. 4, media's obligation to provide correct information to public opinion.

${ }^{15}$ Article 12 para. 1 of Law no. 544/2001: "The following information is exempted from free access by citizens (...):

a) information in the field of national defense, security and public order, if they are part of the categories of classified information, according to the law;

b) information on the deliberations of the authorities, as well as those concerning the economic and political interests of Romania, if they are part of the category of classified information, according to the law;

c) information on commercial or financial activities, if their publicity infringes the intellectual or industrial property right, as well as the principle of fair competition, according to the law;

d) information on personal data, according to the law;

e) information on the procedure during the criminal or disciplinary investigation, if the result of the investigation is endangered, confidential sources are disclosed or the life, bodily integrity, health of a person are endangered as a result of the investigation carried out or in progress;

f) information on judicial proceedings, if their publicity is prejudicial to ensuring a fair trial or the legitimate interest of any of the parties involved in the proceedings;

g) information whose publication prejudices the measures for the protection of young people."

${ }^{16}$ Article 24 para. 5 of Law no. 182/2002 provides that "it is forbidden to classify information, data or documents as state secrets in order to conceal violations of law, administrative errors, limit the access to information of public interest, unlawful restriction of the exercise of rights of some person or damage of other legitimate interests". 
In the doctrine, it was stated that the provision contained in para. 4 of Article 31 of the Romanian Constitution "highlights the great imperatives that must be respected in information matters, namely accuracy, honesty, discretion and of course correctness"17.

The autonomy of the public radio and television services is a benchmark set by the constitutional norm that requires the adoption of an organic law regarding their organization and the parliamentary control of their activity ${ }^{18}$.

The guarantor of the public interest in the field of audiovisual communication is the National Audiovisual Council (CNA) - an autonomous public authority put under parliamentary control. The relation between Parliament and CNA - regulated by the Law no. 504/2004 of the audiovisual, is important not only from the perspective of the relations between the Parliament and the public radio and television companies, but also of the relations between the Parliament and the private companies of profile, since the audiovisual license is issued/raised, on the basis of a decision of the Council, according to the law, that is to say, a regulation of the legislative forum.

\subsection{Limits on the right to information}

As it has been judiciously stated in the specialized literature, "the limitations or conditions brought to fundamental rights/freedoms are realized even on the basis of the constitutional text that regulates them, precisely because they relate to the naturalness of their content, constituting, at the same time, a constant of the fundamental right/freedom"19.

It is clear from the analysis of the constitutional text that the constituent legislator has enshrined both the right to information (Article 31 para. 1 of Romanian Constitution) and its limits (Article 31 para. 3 of Romanian Constitution).

The conditions and limitations applied to fundamental rights must be adequate for the finality pursued by the constituent legislator, that of protecting the fundamental right in situations where it can be conditioned or limited.

As we have shown, developing the constitutional norm, Article 12 of Law no. 544/2001 beside the information in the field of national defense, security and public order, if they belong to the categories of classified information [letter a)] and to those whose publication it prejudices the measures of protection of the young people [letter g)], except from the free access of the citizens other information of public interest, which they are enumerated in limitative fashion [letters b)-f)].

17 I. Muraru, E.S. Tănăsescu, op. cit., p. 182.

${ }_{18}$ The organic law to which the constitutional text concerns is Law no. 41/1994 on the organization and functioning of the Romanian Society of Radio and the Romanian Society of Television, published in the Official Gazette of Romania no. 153 of June $18^{\text {th }}, 1994$.

${ }^{19}$ M.M. Pivniceru, K. Benke, Receiving the proportionality's principle in the jurisprudence of Romanian Constitutional Court. German Constitution's influences, in Constitutional Law Magazine no. 1/2015, p. 63. 
In this respect, it is noteworthy that the specialized doctrine is unanimous in considering that the legislator may impose by law any other limits of the exercise of this fundamental right, but only in compliance with the framework imposed by Article 53 of the Romanian Constitution.

In accordance with the doctrinal approach, the constitutional litigation court ruled that "the legislator is the one who has the right to establish both the conditions and the situations in which certain categories of information are excepted from the free access of citizens", and the exemption provided by Article 12 of Law no. 544/2001 is legitimized even by the constitutional provisions of Article 31 para. 3, as well as of Article 53 of Romanian Constitution ${ }^{20}$.

The limitations or conditions brought to fundamental rights/freedoms are realized according to the constitutional text that regulates them, precisely because they are related to the naturalness of their content, constituting, at the same time, a constant of the fundamental right/freedom. Thus, they do not intervene in the exceptional situations that occur in the life of a company at any given time, do not reflect any deviation from the ordinary and, consequently, have no ephemeral existence or temporal efficiency.

\section{Restricting the exercise of the right to information. The impact of states}

\section{of emergency on the right to information}

Free access to information of public interest is a right whose exercise is relative, not absolute. Thus, the right to information is susceptible to the restriction of its exercise, under the conditions of Article 53 of the Romanian Constitution ${ }^{21}$.

Regarding Article 53 of the Romanian Constitution, in the specialized literature it is appreciated that "its scope concerns the hypothesis in which an infringement of the fundamental right/freedom was found, an infringement due to exceptional conditions arising in the life of the state (...) that, in this case, the legislative measure violated the right, without being annihilated/denied, since, in this case, neither Article 53 of the Constitution can no longer constitute a constitutional justification for the intervention operated on the fundamental right/freedom. This right could continue to be exercised,

${ }^{20}$ Decision no. 437/2019, published in the Official Gazette of Romania no. 847 of October $18^{\text {th }}, 2019$ and Decision no. 1175/2007, published in the Official Gazette of Romania no. 56 of January 24th, 2008.

${ }^{21}$ Article 53 of the Romanian Constitution, with the marginal title "Restriction on the exercise of certain rights or freedoms", provides that:

"(1) The exercise of certain rights or freedoms may only be restricted by law, and only if necessary, as the case may be, for the defense of national security, of public order, health, or morals, of the citizens' rights and freedoms; conducting a criminal investigation; preventing the consequences of a natural calamity, disaster, or an extremely severe catastrophe.

(2) Such restriction shall only be ordered, if necessary, in a democratic society. The measure shall be proportional to the situation that caused it, applied without discrimination and without infringing on the existence of such right or freedom".

STUDIES AND ARTICLES 
but not in its fullness (...) the legislator being obliged, after the termination of the situation that has determined such a measure, to return to the exercise of the respective fundamental right/freedom, in the fullness of its content"22.

In the specialized doctrine ${ }^{23}$, it was pointed out that the constitutional provision allows the restriction of the exercise of citizens' rights and freedoms, but only as an exception, with the following conditions: a) only by law (the notion of law in the material sense, that is the legal norm of the law level, which has as a consequence the fact that such a restriction can also be done by Government Ordinance); b) only if it is required, as the case may be, for the defense of national security, of order, of public health or morals, of the rights and freedoms of citizens; conducting criminal investigation; preventing the consequences of a natural calamity, a disaster or a particularly serious accident; c) not to prejudice the existence of the right or the freedom (it is about restricting the exercise of the right, and not of the right itself); d) be proportional to the situation that determined it (which implies an examination of the measure in relation to the concrete conditions that determined its adoption); e) the measure by which the restriction operates is non-discriminatory (concretizing the principle of equality).

The constitutional text largely resumes the provisions of para. 2 of Article 8-11 of the ECHR, in whose interpretation the ECtHR has ruled the conditions that an interference with the exercise of a right must fulfil in order to be considered as according to the Convention, respectively: a) the interference must be provided by law; b) the interference must pursue a legitimate purpose; c) the interference must be necessary in a democratic society.

The restriction of the exercise of fundamental rights and freedoms inevitably occurs in the case of exceptional measures necessary to be taken to remove serious dangers that threaten the fundamental social values or even the existence and functioning of the state.

The Article 93 of the fundamental law stipulates the possibility of the President of Romania to declare, according to the law, the state of siege or the state of emergency throughout the country or in some administrative-territorial units, with the obligation to ask Parliament to approve the measure adopted in maximum 5 days after taking it.

The distinction and the regulatory area of these two exceptional measures (the state of siege and the state of emergency), enshrined in the constitutional text, was achieved through Government Emergency Ordinance no. 1/1999 regarding the state of siege regime and the state of emergency regime ${ }^{24}$, approved with modifications and completions by Law no. 453/2004 25 .

Without proposing to analyse the complexity of the legal consequences that derive from the establishment of exceptional states, it is important to identify the limits in

${ }^{22}$ M.M. Pivniceru, K. Benke, op. cit., p. 64.

${ }^{23}$ M. Safta, op. cit., pp. 242-243.

${ }^{24}$ Published in the Official Gazette of Romania no. 22 of January 21 2 st 1999.

${ }^{25}$ Published in the Official Gazette of Romania no. 1052 of November 12 2004.

CONSTITUTIONAL LAW REVIEW 
which, in such situations, the restriction of the exercise of fundamental rights and freedoms can occur.

The category of fundamental rights and freedoms whose exercise can be restricted during the establishment of the state of siege or of the state of emergency can be determined, in a first phase, by identifying the measures- grouped in the Article 20 of the Government Emergency Ordinance no. 1/1999, which can be ordered by the decree of the President of Romania.

Article 4 of the Government Emergency Ordinance no. 1/1999, in the form modified by Law no. 453/2004, states that "during the state of siege or the state of emergency, the exercise of fundamental rights and freedoms may be restricted, except for human rights and the fundamental freedoms provided in Article $3^{2}$, only to the extent that the situation requires it and in compliance with Article 53 of the Romanian Constitution, republished".

According to Article $3^{2}$ of the Government Emergency Ordinance no. 1/1999, "during the state of siege and the state of emergency, the following are prohibited: a) limitation of the right to life, except in cases where the death is the result of lawful acts of war; b) torture and inhuman or degrading treatment or punishment; $c$ ) the conviction for unforeseen offenses as such, according to national or international law; d) restriction of free access to justice".

The corroborated analysis of the mentioned legal provisions imposes the conclusion that the exercise of the right to information, not being included among the limiting cases consecrated to be prohibited by Article $3^{2}$ of Government Emergency Ordinance no. 1/1999, can be restricted under the conditions of Article 53 of the Romanian Constitution.

Observing the prerogatives conferred on the military authorities, as well as the other public authorities provided in the decree establishing the state of siege or emergency, listed in Article 20 of the Government Emergency Ordinance no. 1/1999, in terms of the law that is the subject of the present study, we identify:

- protect the military information intended to be communicated through the media; information regarding the state of siege or state of emergency, with the exception of those relating to disasters, shall be released only with the approval of the military authorities; mass media, regardless of the nature and form of the property, are obliged to transmit, with priority, the messages of the military authorities, at their request [letter i)];

- temporarily suspend the appearance or distribution of publications or broadcasts of radio or television stations [letter $\mathrm{k}$ )].

Undoubtedly, the efficiency of the measures instituted during the siege or the emergency state is given by informing the population of the measures to be taken, by correctly informing the public opinion on their need and effectiveness from the perspective of the benefits brought. 


\section{Anca-Jeanina NITĂ}

The constitutional requirement of the correct information of the public opinion, desirable to manifest itself permanently, is invoked more strongly in exceptional situations, when the fight against misinformation is absolutely legitimate and necessary.

However, the state of siege or emergency should not be a pretext for governmental control of information, the provision of truncated information or the lack of transparency.

In addition, it is natural to be given that, "the exceptional measures are not/should not be outside the existing constitutional and legal order, and the effective measures ordered by the public authorities in the state of emergency are entirely part of the constitutional order and it must comply with the legislation in force, just as the citizens have the responsibility and obligation to respect the behavioral norms established by the state authorities" ${ }^{26}$.

\section{The impact of Decree no. 195/2020 for instituting the state of}

\section{emergency in the Romanian territory upon the right to information}

By the Decree of the President of Romania no. 195 of March $16^{\text {th }}, 2020^{27}$ it was officially declared a state of emergency ${ }^{28}$ throughout the territory of Romania for a period of 30 days.

According to Article 2 of the Decree no. 195/2020: "in order to prevent the spread of COVID-19 and to achieve the consequence management, in relation to the evolution of the epidemiological situation, during the state of emergency, the exercise of the following rights is restricted, in proportion to the degree of fulfilment of the criteria provided by the Article 4 para. 4: a) free movement; b) the right to intimate, family and private life; c) the inviolability of the home; d) the right to education; e) the freedom of assembly; f) the right to private property; g) the right to strike; h) the economic freedom".

In the annexes, integral parts of the Decree, were set the first emergency measures with direct applicability (Annex no. 1), respectively with gradual applicability (Annex no. 2), which are required to be taken during the state of emergency.

${ }^{26}$ B. Dima, The state of emergency will be constitutional or unconstitutional at all, in Universul Juridic Magazine no. 3/2020.

${ }^{27}$ Published in the Official Gazette of Romania no. 212 of March $16^{\text {th }}, 2020$.

${ }^{28}$ The state of emergency represents, according to Article 3 of Government Emergency Ordinance no. 1/1999, in the form modified by Law no. 453/2004: "the set of exceptional measures of political, economic and public order nature applicable throughout the country or in some administrative-territorial units that are set up in the following situations: a) the existence of current or imminent serious dangers regarding national security or the functioning of constitutional democracy; b) the imminence of producing or producing calamities that make it necessary to prevent, limit or remove, as the case may be, the consequences disasters".

\section{CONSTITUTIONAL LAW REVIEW}


In addition to the emergency measures established by the decree, additional restrictions may be imposed during the state of emergency by the competent authorities, by military orders and orders.

The application of the measures's management established by the military ordinances or by the order of the Secretary of State, head of the Department for Emergency Situations or his legal substitute, is the responsibility of the Ministry of Internal Affairs, as provided by Article 4 para. 5 of the Decree no. 195/2020.

Through its decision no. 3 of March $19^{\text {th }}, 2020^{29}$ the Parliament ${ }^{30}$ approved the introduction of a state of emergency throughout Romania, as an exceptional measure adopted by the President of Romania by Decree no. 195/2020.

Among the rights whose exercise is restricted during the state of emergency, listed by Article 2 of the Decree no. 195/2020, the right to information is not mentioned.

In Annex no. 1, "First-aid measures with direct applicability", we find regulations that impact the right to free expression and bring amendments to the legislation on free access to information of public interest. We refer, on the one hand, to the dispositions of Article $54^{31}$ of Decree no. 195/2020, which are establishing a mechanism that makes it possible to "eliminate from the source" or "block access of users in Romania to content that promotes fake news regarding the evolution of COVID-19", and on the other hand, to the provisions of Article 56 of Decree no. 195/2020 - which double the legal deadlines set for solving the requests made in the exercise of free access to information of public interest, as well as petitions.

Although the preoccupation of the authorities to combat the dissemination of false information related to the pandemic crisis is absolutely natural, being undeniable that

${ }^{29}$ Published in the Official Gazette of Romania no. 224 of March 19th 2020.

${ }^{30}$ We emphasize that Parliament approved the state of emergency, but not the concrete measures provided by the decree.

${ }^{31}$ Article 54 of Decree no. 195/2020: “(1) Public institutions and authorities, as well as private operators, contribute to the public information campaign on the measures adopted and the activities carried out at national level. (2) In case of spreading false information in mass-media and in the online environment regarding the evolution of COVID-19 and the protection and prevention measures, the public institutions and authorities take the necessary measures to inform the population correctly in this context. (3) Service providers hosting and content providers are obliged, at the reasoned decision of the National Authority for Administration and Regulation in Communications, to immediately discontinue, with the information of the users, the transmission in an electronic communications network or the storage of the content, by eliminating it at the source, if by that content promotes fake news about the evolution of COVID-19 and the protection and prevention measures. (4) Assuming that the elimination at source of the content provided in para. 3 is not feasible, the providers of electronic communications networks intended for the public are obliged, at the reasoned decision of the National Authority for Administration and Regulation in Communications, to immediately block access to that content and to inform the users. (5) At the reasoned decision of the National Authority for Administration and Regulation in Communications, the providers of electronic communications networks for the public have the obligation to immediately block the access of the users in Romania to the content that promotes fake news regarding the evolution of COVID-19 and to the protection and prevention measures and is transmitted in an electronic communications network by the persons from para. 3 who are not under the jurisdiction of national law".

STUDIES AND ARTICLES 
the correct information of the citizens is essential for the management of the crisis situation, many voices in the civil society have invoked that by the regulation enshrined in Article 54 of Decree no. 195/2020, the freedom of the press is endangered. It was invoked that this mechanism creates the premises for the censorship of the right to free expression and will also affect the right to information, that it is not the Government which is the 'court' that has to establish the truth value of the information offered by the media.

Towards this concern expressed in the public space, the Ministry of Internal Affairs came with "Specifications" 32 , pointing out that this tool concerns the fight against actions of misinformation which aim to induce panic through publications without identity or those that systematically present baseless information and that the regulation does not concern press institutions recognized at public opinion level, with established identity and with whom the authorities are in permanent collaboration and dialogue.

Under the mechanism created by Article 54 of the Decree no. 195/2020, observing the guarantees of the legal provision, according to which ANCOM's decision must be motivated, and the measure and motivation brought to the users' notice, we have the hope that the fears are unjustified. The hope is sustained by observing the contents of ANCOM's Decisions for the implementation of Decree no. 195/2020's provision ${ }^{33}$, which are rigorously argued and explicitly mention the possibility of being subjected to the legality control of the administrative litigation court.

However, we fully understand the concern of civil society and the "alarm signal" regarding "the tendency of some public authorities to limit the access to information of public interest, invoking the provisions regarding the state of emergency" and we think that the appeal to the Romania's Government, especially to the Ministry of Internal Affairs $^{34}$, to ensure transparency of public authorities, in order to respect the right of access to public information must not only be heard, but also listened to.

We support this opinion with the fact that the information of public interest related to the current activity of the authorities in the context of the pandemic has a legal and constitutional basis that cannot be ignored and scorned, and between the main tasks of the National Committee for emergency situations we find "coordinating the information of the public opinion regarding the management of emergency situations", and not the "centralization" of information.

Last but not least, we would like to point out that the concern of the civil society regarding the "information blockade" was also shared by the press representative of

32 MAI communique available at https://www.mai.gov.ro/precizare-23/.

${ }^{33}$ Decisions no. 454, March 26 $6^{\text {th }}, 2020$, no. 482, April $7^{\text {th }}, 2020$, no. 485 April $10^{\text {th }}$ 2020, available at https://www.ancom.ro/decizii-decret-stare-de-urgenta_6253.

${ }^{34}$ In order to see the Center for Independent Journalism's appeal, check https://www.romaniacurata.ro/ accesul-la-informatiile-publice-nu-trebuie-sa-devina-o-victima-a-pandemiei-de-covid-19/.

\section{CONSTITUTIONAL LAW REVIEW}


OSCE (Organization for Security and Cooperation in Europe), who expressed her fears about the provisions of the state of emergency's establishment decree that gives to the government special powers to limit freedom of information ${ }^{35}$.

The "full transparency insurance" given by The National Committee for Special Emergency Situations and the newsletters issued by the Strategic Communication Group in which the statistical data on the evolution of the Covid-19 pandemic in Romania are presented, although necessary, they are not sufficient to satisfy the requirements of Law no. 544/2001.

Moreover, the "transparency assurances" received from the authorities are contradicted by the newly added Article $33^{1}$ of the Government Emergency Ordinance no. 1/1999: "during the period of the siege or the state of emergency, the legal norms regarding the decision-making transparency and the social dialogue do not apply in case of draft normative acts establishing measures applicable for the duration of the state of siege or the state of emergency or which are a consequence of the establishment of these states".

The Romanian Ombudsman ${ }^{36}$ considers that the provisions of Article I pnt. 5 of the Government Emergency Ordinance no. 3/2020 - through which Article $33^{1}$ was introduced in Government Emergency Ordinance no. 1/1999, ignores Article 115 para. 6 of the Romanian Constitution, by violating the constitutional requirement that conditions the legislative delegation to respect the prohibition regarding the impairment of constitutional rights and freedoms, as well as Article 41 and Article 31 of the Romanian Constitution concerning the right to work, the social protection of work and the right to information ${ }^{37}$.

In the Government Emergency Ordinance no. 34/2020's preamble, the delegated legislator, referring to the specific state of emergency established by the Decree no. $195 / 2020$, argues the need to suspend the application of the legal norms with regard to transparency in decision-making and social dialogue, starting from the premise that they affect the speed with which one can take normative measures to be applied for the duration of the state of emergency or which are a consequence of declaring the state.

We agree with the opinion of the Ombudsman, expressed in the censure of Article I pnt. 5 of the Government Emergency Ordinance no. 34/2020, in the sense that "the

\footnotetext{
${ }^{35}$ See https://romania.europalibera.org/a/osce-romania-nu-trebuie-sa-limiteze-accesul-la-informa\%C8\% 9Bii-prin-stare-de-urgenta/30519642.html.

${ }^{36}$ The Romanian Ombudsman notified the Constitutional Court with the exception of unconstitutionality regarding the provisions of Article 9, Article 14 letters c1)-f) and Article 28 of the Government Emergency Ordinance no. 1/1999 regarding the state of siege regime and the state of emergency regime, as subsequently amended and supplemented, and to the Government Emergency Ordinance no. 34/2020 for amending and completing the Government Emergency Ordinance no. 1/1999 regarding the regime of the state of siege and the regime of the state of emergency, as a whole.

37 The exception of unconstitutionality, registered at the Romanian Constitutional Court with no. 2077, April 16 ${ }^{\text {th }}, 2020$, available at http://www.avpoporului.ro/.
}

STUDIES AND ARTICLES 
Anca-Jeanina NITĂ

premise from which one should start is that the rule of law, even during the state of emergency, establishes a series of safeguards meant to ensure the respect of citizens' rights and freedoms, as well as the inclusion of public authorities in the coordinates of the law".

The reality has shown us that the multiple social, economic, political consequences of a crisis situation cannot be dissociated from their legal dimension. It is natural for it to be so, since "although the state of emergency has a constitutionally and legally profound derogatory legal regime as an exception, it stays part of the constitutional and legal order of the Romanian state" 38 .

${ }^{38}$ B. Dima, op. cit. 